\title{
Clinical Effects Of Acupuncture On The Pathophysiological Mechanism Of Chronic Obstructive Pulmonary Disease During Exercise
}

This article was published in the following Dove Press journal: International Journal of Chronic Obstructive Pulmonary Disease

\author{
Tomonori Maekura $\mathbb{D}^{1,2}$ \\ Keisuke Miki' \\ Mari Miki ${ }^{1}$ \\ Seigo Kitada $\mathbb{D}^{\prime}$ \\ Ryoji Maekura $\mathbb{D}^{1,2}$
}

'Department of Respiratory Medicine, National Hospital Organization Osaka Toneyama Medical Center, Toyonaka, Japan; ${ }^{2}$ Course of Safety Management in Health Care Sciences, Graduate School of Health Care Sciences, Jikei Institute, Osaka, Japan
Correspondence: Ryoji Maekura

Course of Safety Management in Health

Care Sciences, Graduate School of Health

Care Sciences, Jikei Institute, I-2-8 Miyahara,

Yodogawa-Ku, Osaka 532-0003, Japan

Tel +8I 661501336

$\mathrm{Fax}+81661501337$

Email r-maekura@ghsj.ac.jp
Purpose: Pharmacological therapy and pulmonary rehabilitation are useful for exertional dyspnoea in patients with chronic obstructive pulmonary disease (COPD); however, several patients have no meaningful improvements. Although acupuncture significantly improves exercise intolerance and dyspnoea, the pathophysiological mechanism of these effects is unknown; therefore, we evaluated this mechanism using cardiopulmonary exercise testing in a single-arm, open experimental study.

Patients and methods: Sixteen patients with COPD underwent acupuncture once a week for 12 weeks. Primary outcomes were exercise performance parameters, including peak oxygen uptake in the incremental exercise tests (IETs) and the time to the limit of tolerance measured in constant work rate exercise tests (CWRETs) at 70\% peak work-rate of the IET. IETs and CWRETs were performed at baseline and at weeks 12, 16, and 24.

Results: During the time course, there were significant increases in peak oxygen uptake $(\mathrm{p}=0.018)$ and minute ventilation $\left(\dot{\mathrm{V}}_{\mathrm{E}}, \mathrm{p}=0.04\right)$ in the IETs. At 12 weeks, the endurance time significantly increased $(810 \pm 470 \mathrm{vs} 1125 \pm 657 \mathrm{~s}, \mathrm{p}<0.001)$ and oxygen uptakes at terminated exercise were significantly lower $(771 \pm 149 \mathrm{~mL} / \mathrm{min}, \mathrm{p}<0.05)$ than those at baseline $(822 \pm 176 \mathrm{~mL} / \mathrm{min})$ in CWRETs. The significant decreases in oxygen uptake and minute ventilation and improvements in Borg scale scores were also observed during CWRETs after acupuncture. The decreases at isotime in the Borg scale $(r=-0.789, p=0.0007)$ and $\dot{V}_{E}(r=-0.6736, p=0.0042)$ were significantly correlated with the improvement of endurance time.

Conclusion: The positive effects of acupuncture on exertional dyspnoea were associated with increased endurance time influenced by improved oxygen utilisation and reduced ventilation during exercise. Acupuncture may be a new intervention for COPD in addition to conventional maintenance therapies.

Keywords: chronic obstructive pulmonary disease, COPD, acupuncture, exercise intolerance and dyspnoea, cardiopulmonary exercise test, CPET

\section{Plain Language Summary}

Although acupuncture significantly improves exercise intolerance and dyspnoea, the pathophysiological mechanism of these effects is unknown; we evaluated this mechanism using cardiopulmonary exercise testing. We found that peak oxygen uptake and ventilation capacity significantly improved in the IETs and the endurance time significantly increased in the CWRETs. The Borg scale scores, oxygen uptake, and minute ventilation were significantly lower during CWRET after acupuncture than those at baseline. These results indicated that COPD patients treated with acupuncture have been able to exercise with less oxygen consumption and ventilation. The positive 


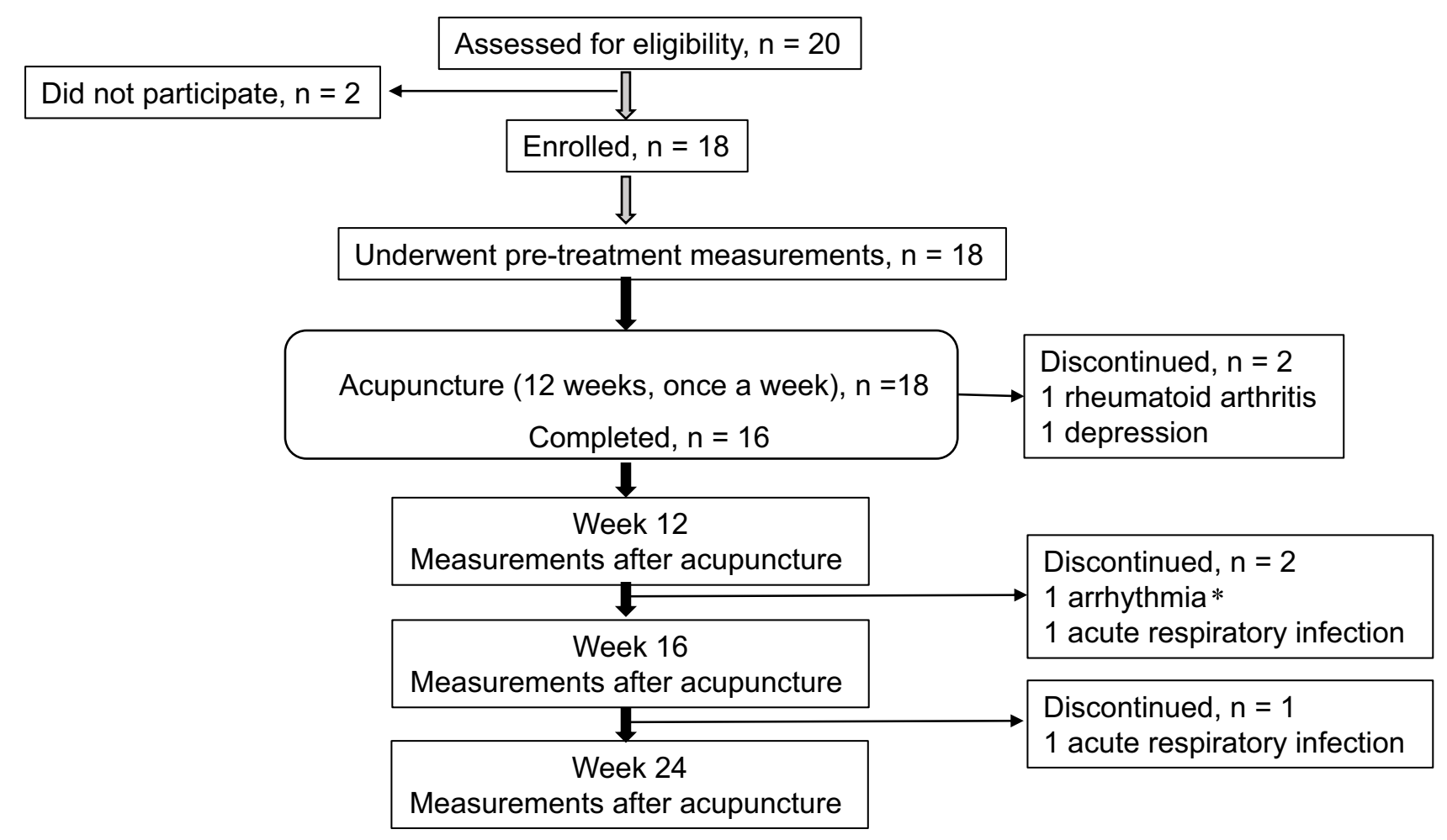

Figure I Trial profile. *The patient experiencing exertional arrhythmia during cardiopulmonary exercise testing (CPET) at 12 weeks underwent further follow-up examinations except for cardiopulmonary exercise testing.

effects of acupuncture on exertional dyspnoea were mainly associated with increased endurance time influenced by improved oxygen utilisation and reduced ventilation during exercise.

\section{Introduction}

Chronic obstructive pulmonary disease (COPD) is characterised by irreversible airflow limitation and is currently the third leading cause of death worldwide in 2018. ${ }^{1}$ Exertional dyspnoea, the most debilitating symptom of COPD, affects many aspects of daily living. ${ }^{2,3}$ Dyspnoea can progressively increase in severity and predicts the survival of patients with COPD. ${ }^{4,5}$ Therefore, dyspnoea management is an important target in COPD. Pharmacological therapy for COPD, such as bronchodilators, can reduce symptoms and the frequency and severity of exacerbations and improve exercise intolerance and health status. ${ }^{6,7}$ Pulmonary rehabilitation also alleviates symptoms and has socioeconomic benefits. ${ }^{8,9}$ We previously reported that personalised pulmonary rehabilitation, including occupational therapy (PPR-OT), improves the survival of patients with advanced COPD. ${ }^{10}$ We had experienced that 34 cases $(18.4 \%)$ had no improvements in exercise intolerance and dyspnoea in 185 patients with PPR-OT. Several patients also showed no meaningful clinical improvements in response to well-established treatments. ${ }^{11}$ For these patients, it is necessary to develop new options in addition to conventional therapies.

Acupuncture significantly improves exercise intolerance, dyspnoea on submaximal exercise, and quality of life in patients with COPD. ${ }^{12,13}$ Acupuncture is an oriental medicine, and some of its physiological benefits include relaxation of muscle tension, improvement of muscle/anti-muscle fatigue, improvement of muscle blood flow, and sympathetic control. ${ }^{14-16}$ Considering these benefits, acupuncture may be effective in treating COPD-associated skeletal muscle disorders. However, the pathophysiological mechanism for how exercise capacity is improved by acupuncture is currently unknown. In the present study, the effect of acupuncture on the pathophysiological mechanism of COPD during exercise was evaluated using cardiopulmonary exercise tests (CPETs) for the first time.

\section{Subjects And Methods}

\section{Patient Recruitment}

This single-arm, open experimental study was conducted from May 25, 2015, to May 30, 2017, at the National Hospital Organization Osaka Toneyama Medical Center. All participants met the following criteria: 1) COPD diagnosed and classified as stage II or more according to the 
Table I Patients' Baseline Characteristics ( $\mathrm{N}=16)$

\begin{tabular}{|c|c|c|c|c|}
\hline & Mean & SD & Min & Max \\
\hline $\begin{array}{l}\text { Age, years } \\
\text { Sex, male/female } \\
\text { BMI, } \mathrm{kg} \cdot \mathrm{m}^{-2} \\
\text { Cigarette smoking, pack years } \\
\text { GOLD, I/II/III/IV, number }\end{array}$ & $\begin{array}{l}72.7 \\
16 / 0 \\
21.9 \\
56.1 \\
0 / 7 / 8 / 1\end{array}$ & $\begin{array}{l}3.0 \\
21.1\end{array}$ & $\begin{array}{l}15.0 \\
25\end{array}$ & $\begin{array}{l}25.7 \\
96\end{array}$ \\
\hline $\begin{array}{l}\text { Pulmonary function tests } \\
\qquad \text { FEV }_{1}, \mathrm{~L} \\
\text { \%FEV }, \text { \%predicted } \\
\mathrm{FEV}_{1} / \mathrm{FVC}, \% \\
\text { VC, L } \\
\text { \%VC, \% }\end{array}$ & $\begin{array}{l}1.40 \\
50.6 \\
43.0 \\
3.32 \\
93.2\end{array}$ & $\begin{array}{l}0.51 \\
17.2 \\
13.9 \\
0.52 \\
11.9\end{array}$ & $\begin{array}{l}0.79 \\
26.6 \\
28.5 \\
2.27 \\
77.4\end{array}$ & $\begin{array}{l}2.36 \\
79.7 \\
68.6 \\
4.04 \\
115.7\end{array}$ \\
\hline $\begin{array}{l}\text { Incremental work rate exercise } \\
\text { testing At peak exercise } \\
\text { Dyspnoea, Borg scale } \\
\dot{\mathrm{V}}_{\mathrm{O} 2}, \mathrm{~mL} \cdot \mathrm{min}^{-1} \cdot \mathrm{kg}^{-1}\end{array}$ & $\begin{array}{l}6.1 \\
14.3\end{array}$ & $\begin{array}{l}1.7 \\
3.2\end{array}$ & $\begin{array}{l}3 \\
8.3\end{array}$ & $\begin{array}{l}9 \\
20.0\end{array}$ \\
\hline $\begin{array}{l}\text { Constant work rate exercise testing } \\
\text { Time to the limit of tolerance } \\
\text { (tLIM), s }\end{array}$ & 810 & 470 & 351 & $|88|$ \\
\hline $\begin{array}{l}\text { SGRQ scores } \\
\text { Total } \\
\text { Symptoms } \\
\text { Activity } \\
\text { Impacts }\end{array}$ & $\begin{array}{l}40.4 \\
49.9 \\
56.9 \\
28.1\end{array}$ & $\begin{array}{l}16.3 \\
22.7 \\
17.9 \\
17.0\end{array}$ & $\begin{array}{l}9.4 \\
9.6 \\
18.5 \\
4.2\end{array}$ & $\begin{array}{l}76.4 \\
76.4 \\
92.5 \\
67.1\end{array}$ \\
\hline $\begin{array}{l}\text { Medications, number } \\
\text { LAMA } \\
\text { LABA } \\
\text { SABA } \\
\text { ICS } \\
\text { Methylxanthines }\end{array}$ & $\begin{array}{l}16 \\
7 \\
2 \\
7 \\
2\end{array}$ & & & \\
\hline
\end{tabular}

Notes: Data are presented as the mean, standard deviation (SD) and the minimum-maximum values. Medications are presented separately. Evaluations for eligibility, including pulmonary function testing, were performed before pre-treatment measurements.

Abbreviations: BMI, body mass index; GOLD, Global Initiative for Chronic Obstructive Lung Disease category; $\mathrm{FEV}_{1}$, forced expiratory volume in one second; FVC, forced vital capacity; ICS, inhaled corticosteroids; LAMA, long-acting muscarinic antagonist; LABA, long-acting $\beta_{2}$-agonist; SABA, short-acting $\beta_{2}$-agonist; SGRQ, St George's Respiratory Questionnaire; tLIM, time to the limit of tolerance; VC, vital capacity; $\dot{\mathrm{V}}_{\mathrm{O} 2}$, oxygen uptake.

GOLD criteria $^{17}$ and rated as grade $\geq 1$ according to modified Medical Research Council dyspnoea scale; 2) age $\geq 40$ years; and 3) stable condition to ensure an adequate CPET evaluation. Participants were excluded owing to any of the following reasons: 1) malignant tumour, 2) active infection, 3) severe heart disease, 4) hepatic dysfunction, 5) renal failure, 6) change in drug regimen, 7) ongoing pulmonary rehabilitation during the study, and 8) inability to participate as determined by their physician.

\section{Acupuncture Intervention}

The patients underwent acupuncture once a week for 12 weeks, in addition to their daily medications. The following 11 standardised acupuncture points were selected according to previous research: lung meridian, LU1 (Zhongfu) and LU9 (Taiyuan); large intestine meridian, LI18 (Futu); conception vessel, CV4 (Guanyuan) and CV12 (Zhongwan); stomach meridian, ST36 (Zusanli); kidney meridian, KI3 (Taixi); gallbladder meridian, GB12 (Wangu); and bladder meridian, BL13 (Feishu), BL20 (Pishu), and BL23 (Shenshu). ${ }^{13}$ No other acupuncture points were used. Therapeutic acupuncture needles (stainless steel; disposable; length, $40 \mathrm{~mm}$; thickness, $0.16 \mathrm{~mm}$; SEIRIN, Shizuoka, Japan) were inserted to a depth of 5 to $25 \mathrm{~mm}$ and manually rotated counter-clockwise for $10 \mathrm{~s}$ to 1 min during the 50-min treatment period. Perception of de qi (ie, tingling, numbness, heaviness, and other feelings) was confirmed after needle insertion and manipulation. The acupuncturist had been treating respiratory patients for $>5$ years at the study institution.

\section{Pulmonary Function Tests}

Spirometry measurements (Autospirometer System 9; Minato Medical Science, Osaka, Japan) were obtained in accordance with the recommendations of the American Thoracic Society before the CPET at baseline and at 12 and 24 weeks. ${ }^{18,19}$

\section{Cardiopulmonary Exercise Tests}

CPETs were performed at baseline and at 12, 16, and 24 weeks.

\section{a) Incremental exercise test (IET)}

Symptom-limited incremental exercise tests were performed using an electrically braked cycle ergometer (CV1000SS; Lode, Groningen, Netherlands) and a CPET system (Marquette CASE series T 2001, GE Healthcare, Tokyo, Japan; Aero monitor AE310S, Minato Medical Science Co., Ltd, Osaka, Japan; and pulse oximeter Pulsox-M24, Teijin Co Ltd, Tokyo, Japan) with the following protocol: starting with zero workload, the power was progressively increased by increments of $10 \mathrm{~W}$ every 2 mins, as previously described. ${ }^{20,21}$ The following parameters were obtained: heart rate, respiratory frequency, tidal volume, minute ventilation $\left(\dot{\mathrm{V}}_{\mathrm{E}}\right)$, oxygen uptake $\left(\dot{\mathrm{V}}_{\mathrm{O} 2}\right)$, carbon dioxide output $\left(\dot{\mathrm{V}}_{\mathrm{CO} 2}\right)$, ventilatory equivalent for oxygen $\left(\dot{\mathrm{V}}_{\mathrm{E}} / \dot{\mathrm{V}}_{\mathrm{O} 2}\right)$, ventilatory equivalent for carbon dioxide $\left(\dot{\mathrm{V}}_{\mathrm{E}} / \dot{\mathrm{V}}_{\mathrm{CO} 2}\right)$, saturation pulse oxygenation $\left(\mathrm{Sp}_{\mathrm{O} 2}\right), \mathrm{Sp}_{\mathrm{O} 2}$-slope $\left[\left(\mathrm{Sp}_{\mathrm{O} 2}\right.\right.$ at peak exercise - $\mathrm{Sp}_{\mathrm{O} 2}$ at rest $) /$ $\left(\dot{\mathrm{V}}_{\mathrm{O} 2}\right.$ at peak exercise $-\dot{\mathrm{V}}_{\mathrm{O} 2}$ at rest)], difference $\left(\mathrm{D}-\mathrm{F}_{\mathrm{O} 2} \%\right)$ 
Table 2 Peak Parameters Of The Incremental Exercise Test After 12 Weeks Of Acupuncture Treatment And Follow-Up Data

\begin{tabular}{|c|c|c|c|c|c|}
\hline & Week $0(n=16)$ & Week I $2(n=16)$ & Week I6 $(n=\mid 4)$ & Week $24(n=\mid 3)$ & p-Value (F-Value) \\
\hline Work rate, $\mathrm{W}$ & 47.5 (I7.9) & $50.0(18.0)$ & $50.7(18.7)$ & $52.3(20.1)$ & $0.142(1.918)$ \\
\hline$\dot{\mathrm{V}}_{\mathrm{O} 2}, \mathrm{~mL} \cdot \mathrm{kg}-\mathrm{I} \cdot \mathrm{min}-\mathrm{I}$ & I 4.3 (3.2) & 14.7 (3.9) & $15.0(3.8)$ & $15.0(4.0)$ & $0.018(3.763)$ \\
\hline$\dot{\mathrm{V}}_{\mathrm{O} 2}, \mathrm{~mL} \cdot \mathrm{min}^{-1}$ & $854(201)$ & 874 (229) & 879 (239) & $885(221)$ & $0.039(3.066)$ \\
\hline$\dot{\mathrm{V}}_{\mathrm{CO} 2}, \mathrm{~mL} \cdot \mathrm{min}^{-1}$ & $883(232)$ & 921 (269) & 921 (257) & $931(266)$ & $0.063(2.630)$ \\
\hline Dyspnoea, Borg scale & $6.1(1.7)$ & $6.3(1.8)$ & $6.1(2.1)$ & $6.5(1.9)$ & $0.809(0.322)$ \\
\hline Leg fatigue, Borg scale & $4.7(2.7)$ & $4.8(3.1)$ & $4.6(3.0)$ & $4.9(3.1)$ & $0.797(0.340)$ \\
\hline $\mathrm{V}_{\mathrm{Te}}, \mathrm{L}$ & $1.29(0.33)$ & $1.32(0.40)$ & I.3I (0.36) & $1.34(0.32)$ & $0.805(0.328)$ \\
\hline $\mathrm{V}_{\mathrm{Ti}_{\mathrm{i}}}-\mathrm{V}_{\mathrm{Te}}, \mathrm{mL}$ & $13.9(14.3)$ & $6.4(16.5)$ & I.2 (25.7) & $17.5(20.7)$ & $0.112(2.125)$ \\
\hline$f_{R}$, breaths $\cdot \min ^{-1}$ & $29.1(5.2)$ & $30.4(5.9)$ & $29.6(5.1)$ & $29.7(4.6)$ & $0.334(1.167)$ \\
\hline$\dot{\mathrm{V}}_{\mathrm{E}}, \mathrm{L} \cdot \min ^{-1}$ & $37.0(9.9)$ & $39.3(12.0)^{*}$ & $38.0(9.7)$ & $39.6(11.8)$ & $0.040(3.048)$ \\
\hline $\mathrm{V}_{\mathrm{D}} / \mathrm{V}_{\mathrm{T}}$ & $0.37(0.04)$ & $0.37(0.05)$ & $0.36(0.05)$ & $0.36(0.04)$ & $0.383(1.046)$ \\
\hline$\dot{\mathrm{V}}_{\mathrm{E}} / \dot{\mathrm{V}}_{\mathrm{O} 2}$ & $43.7(7.5)$ & $45.2(8.0)^{*}$ & $44.5(9.4)$ & $45.1(9.2)$ & $0.306(1.246)$ \\
\hline$\dot{\mathrm{V}}_{\mathrm{E}} / \dot{\mathrm{V}}_{\mathrm{CO} 2}$ & $42.2(5.4)$ & $42.9(5.8)$ & $42.2(8.1)$ & 43.1 (7.9) & $0.631(0.582)$ \\
\hline $\mathrm{HR}$, beats $\cdot \min ^{-1}$ & $121(10)$ & $123(13)$ & $125(14)$ & $125(14)$ & $0.264(1.377)$ \\
\hline $\mathrm{SPO}_{2}, \%$ & $91.4(4.5)$ & $90.3(4.7)$ & $90.1(4.6)$ & $89.3(5.2)$ & $0.132(1.985)$ \\
\hline SPO2-slope, \% $\left(\mathrm{L} \cdot \mathrm{min}^{-1}\right)^{-1}$ & $-10(0.2)$ & $-1 \mathrm{I}(0.2)$ & $-12(0.2)$ & $-12(0.2)$ & $0.898(0.197)$ \\
\hline $\mathrm{DF}_{\mathrm{O} 2}, \%$ & $2.87(0.50)$ & $2.79(0.50)^{*}$ & $2.8 I(0.55)$ & $2.82(0.62)$ & $0.341(1.149)$ \\
\hline $\mathrm{PET}_{\mathrm{CO} 2}, \mathrm{mmHg}$ & $35.8(5.9)$ & $35.4(5.8)$ & $35.8(6.8)$ & $35.4(7.7)$ & $0.740(0.419)$ \\
\hline $\mathrm{Fe}_{\mathrm{CO} 2}, \%$ & $3.17(0.45)$ & $3.13(0.41)$ & $3.21(0.58)$ & $3.14(0.6 I)$ & $0.34 I(1.150)$ \\
\hline AT, $\mathrm{mL} \cdot \mathrm{min}^{-1}$ & $650(168)$ & $647(156)$ & $637(125)$ & $640(150)$ & $0.464(0.875)$ \\
\hline AT, \% & $76.9(10.2)$ & $74.1(10.4)$ & $75.8(10.1)$ & $72.7(7.3)$ & $0.490(0.824)$ \\
\hline Dyspnoea break point, \% & $75.6(2.7)$ & $75.2(2.6)$ & $79(3.8)$ & $78.4(2.9)$ & $0.722(0.449)$ \\
\hline
\end{tabular}

Notes: Data are presented as the mean (standard deviation). Treatment effect: mean difference from pre-treatment value; $* \mathrm{P}<0.05$, pre-treatment vs 12 weeks, paired $t$-test. Dyspnoea break points and ATs at pre-treatment, I2, 16, and 24 weeks were detectable in I5, 15, I4, and I 3 patients and in I4, I4, I2, and II patients, respectively. ${ }^{\mathrm{a}}$ Time course effect of I2-week acupuncture treatment by one-way repeated measures analysis of variance.

Abbreviations: AT, anaerobic threshold; $\mathrm{DF}_{\mathrm{O} 2}$, difference between fractional content of inspired oxygen and fractional content of expired oxygen; Fe ${ }_{\mathrm{CO} 2}$, fractional content of expired carbon dioxide; $\mathrm{f}_{\mathrm{R}}$, breathing frequency; $\mathrm{HR}$, heart rate; $\mathrm{PETCO}_{2}$, end-tidal partial pressure of $\mathrm{CO}_{2} ; \mathrm{V}_{\mathrm{D}} / \mathrm{V}_{\mathrm{T}}$, dead space/tidal volume ratio; $\mathrm{SPO}$, saturation pulse

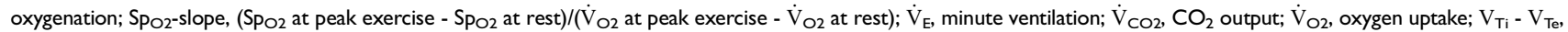
inspiratory tidal volume - expiratory tidal volume.

between fractional content of inspired $\left(\mathrm{Fi}_{\mathrm{O} 2}\right)$ and expired $\left(\mathrm{Fe}_{\mathrm{O} 2}\right)$ oxygen, difference between inspiratory and expiratory tidal volume $\left(\mathrm{V}_{\mathrm{Ti}}-\mathrm{V}_{\mathrm{Te}}\right)$, which indicates the remains of expiration, and oxygen pulse measured on a breath-by-breath basis and presented as 30-s averages at rest, during exercise at 2-min intervals, and at the end of exercise. Dyspnoea was measured using the modified Borg scale. ${ }^{13,22}$ The anaerobic threshold (AT) was identified using the V-slope method, and the nadir of the parameter $\dot{\mathrm{V}}_{\mathrm{E}} / \dot{\mathrm{V}}_{\mathrm{O} 2}$ was measured during exercise. The dyspnoea break points during exercise were determined using the intersection of two lines on individual plots of the Borg scale curve. ${ }^{20}$

\section{b) Constant work rate exercise test (CWRET)}

All participants underwent CWRETs with continuous monitoring of $\mathrm{Sp}_{\mathrm{O} 2}$ and electrocardiograms on a cycle ergometer at $70 \%$ peak WR of the IET completed at least an hour earlier. The criteria for termination included $\leq 10 \mathrm{~s}$ below the lower-bound target frequency of 50-60 rpm despite verbal encouragement. The point at which the patient was unable to regain the target frequency despite encouragement was defined as the time to the limit of tolerance (tLIM). ${ }^{23}$ Submaximal isotime was defined as the end of 30-s averages prior to the time of shorter peak exercise either during baseline or the period after acupuncture.

\section{Respiratory Muscle Strength}

The maximum inspiratory (MIP) and expiratory (MEP) pressures were measured using a standard mouthpiece and a respiratory muscle strength testing device (Vitalopower KH101; Chest M.I., Inc., Tokyo, Japan) according to the American Thoracic Society/European Respiratory Society. ${ }^{24}$

Respiratory system resistances were measured at $5 \mathrm{~Hz}$ (R5) and $20 \mathrm{~Hz}$ (R20) using a commercial forced oscillation technique device (MostGraph1; Chest M.I., Inc.). Daily physical activities, such as total energy expenditure, were measured using a triaxial accelerometer (Actimarker; Panasonic, Osaka, Japan). 
A IET

1)

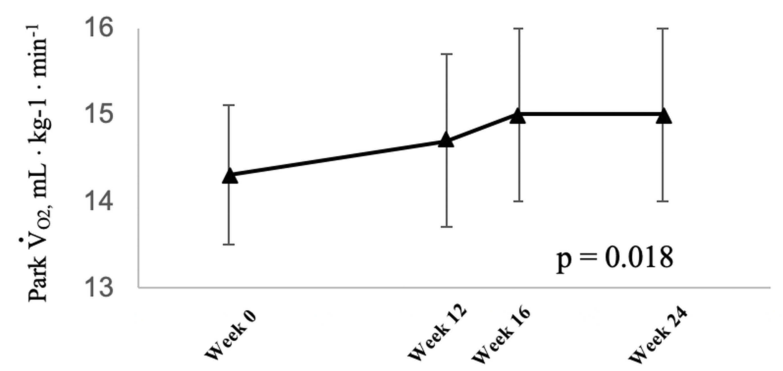

\section{B CWRET}

1)

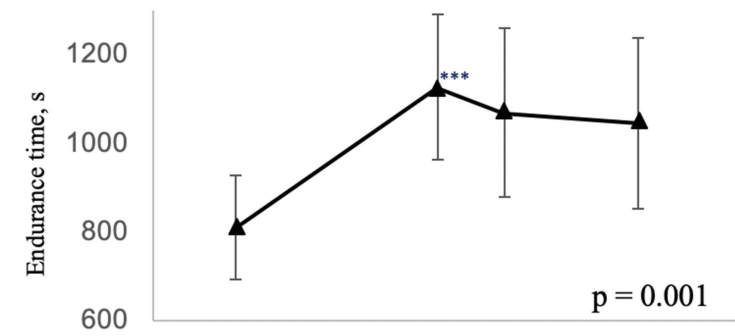

3)

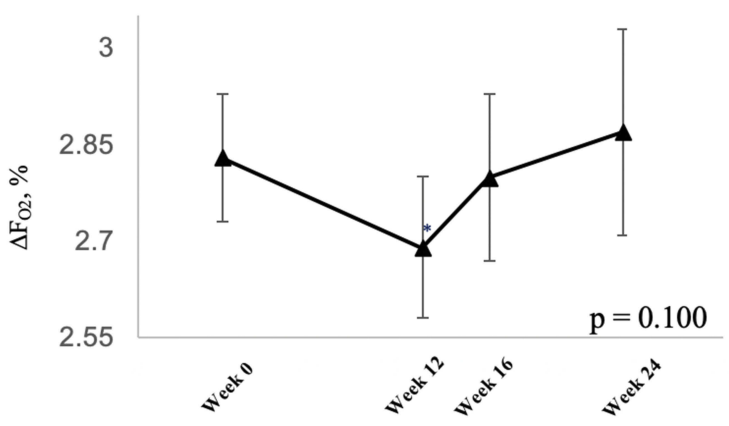

2)

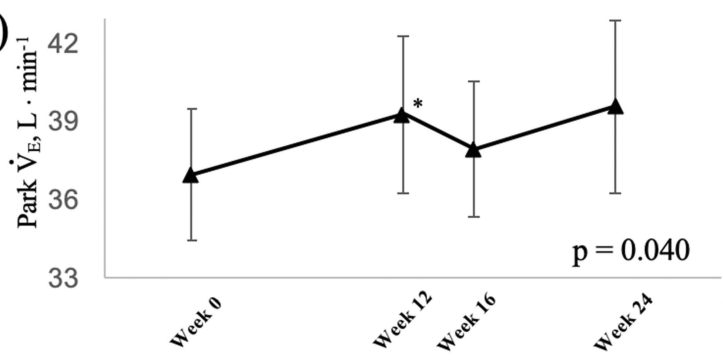

2)

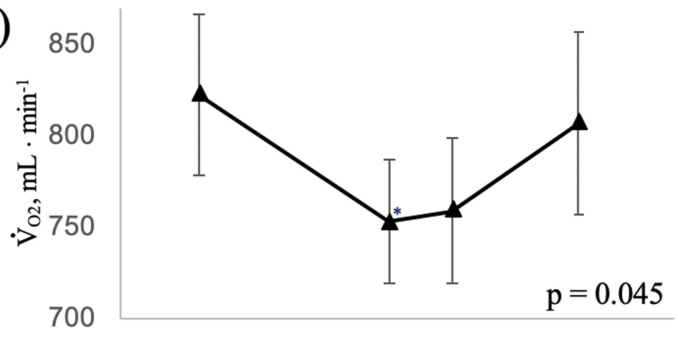

4)

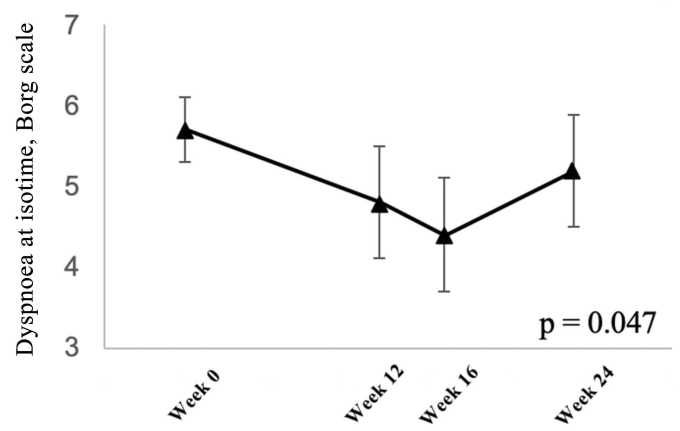

Figure 2 Responses and follow-up data after 12 weeks of acupuncture treatment at maximum exercise in (A) incremental exercise testing (IET): I) peak oxygen uptake and 2) peak minute ventilation. (B) Constant work rate exercise testing (CWRET): I) endurance time, 2) oxygen uptake at terminated exercise, 3) DF $\mathrm{O}_{2}$ at terminated exercise, 4) Borg scale at isotime. Data are expressed as the mean \pm standard error. $\dot{\mathrm{V}}_{\mathrm{O} 2}$ : oxygen uptake; $\dot{\mathrm{V}}_{\mathrm{E}}$ : minute ventilation; $\mathrm{DF}_{\mathrm{O} 2}$ : inspired oxygen concentration (Fi $\mathrm{O}_{2}$ ) - expired oxygen concentration $\left(\mathrm{Fe}_{\mathrm{O} 2}\right)$; p-values: time course effect of I2-week acupuncture treatment by one-way repeated measures analysis of variance; ${ }^{*} \mathrm{p}<0.05$, $* * * \mathrm{p}<0.00 \mathrm{I}$ : pre-treatment vs 12 weeks, paired $t$-test.

\section{Dual-Energy X-Ray Absorptiometry}

To assess body composition, including lean body mass, dual-energy X-ray absorptiometry was performed with patients lying in a supine position.

\section{Primary Outcomes}

Primary outcomes were exercise performance parameters, including peak oxygen uptake $\left(\dot{\mathrm{V}}_{\text {O2peak }}\right)$, representing the highest oxygen uptake achieved in the IET at the subject's limit of tolerance and tLIM measured in CWRET, and the quality of life measured with the St George's Respiratory Questionnaire (SGRQ).

\section{Secondary Outcomes}

Secondary outcomes were forced expiratory volume in one second $\left(\mathrm{FEV}_{1}\right)$, MIP, MEP, total lean body mass, and total energy expenditure.

\section{Sample Size}

The effects of acupuncture have not been previously evaluated using CPET. Therefore, the sample size calculation was using the estimated effect of acupuncture for improving SGRQ. ${ }^{13}$ The sample size of 16 was used to provide the power ( $90 \%$ ) to detect a mean difference of 4 in SGRQ with a standard deviation SD of 3.32 using a two-sided $\alpha$ of $0.05 .^{13}$ 
Table 3 Peak Parameters Of The Constant Work Rate Exercise Test After 12 Weeks Of Acupuncture Treatment And Follow-Up Data

\begin{tabular}{|c|c|c|c|c|c|}
\hline & Week $0(n=16)$ & Week I $2(n=16)$ & Week $16(n=14)$ & Week $24(n=13)$ & p-Value (F-Value) \\
\hline Endurance time, $s$ & $810(470)$ & $1125(657)^{* * *}$ & $1068(7 \mid 4)$ & 1046 (691) & $0.001(7.121)$ \\
\hline$\dot{\mathrm{V}}_{\mathrm{O} 2}, \mathrm{~mL} \cdot \mathrm{kg}^{-1} \cdot \mathrm{min}^{-1}$ & | $3.8(2.8)$ & $12.9(2.3)^{*}$ & I3.2(2.7) & I3.6 (3.I) & $0.038(3.079)$ \\
\hline$\dot{\mathrm{V}}_{\mathrm{O} 2}, \mathrm{~mL} \cdot \mathrm{min}^{-1}$ & $822(176)$ & 77I (149)* & $772(162)$ & 807 (182) & $0.045(2.924)$ \\
\hline$\dot{\mathrm{V}}_{\mathrm{CO} 2}, \mathrm{~mL} \cdot \mathrm{min}^{-1}$ & $798(170)$ & $753(136)$ & 759 (149) & $768(175)$ & $0.174(1.739)$ \\
\hline Dyspnoea, Borg scale & $6.2(1.9)$ & $6.2(2.5)$ & $5.9(2.8)$ & $6.5(2.4)$ & $0.451(0.897)$ \\
\hline Leg fatigue, Borg scale & $5.5(2.4)$ & $5.3(2.8)$ & $5.4(3.1)$ & $5.3(3.3)$ & $0.977(0.068)$ \\
\hline $\mathrm{V}_{\mathrm{Te}}, \mathrm{L}$ & $1.30(0.31)$ & $1.20(0.27)^{* *}$ & $1.22(0.30)$ & $1.23(0.30)$ & $0.014(4.021)$ \\
\hline $\mathrm{V}_{\mathrm{Ti}_{\mathrm{i}}}-\mathrm{V}_{\mathrm{Te}}, \mathrm{mL}$ & $22.3(14.9)$ & $8.1(26.5)$ & $5.4(29.4)$ & $14.9(19.8)$ & $0.159(1.823)$ \\
\hline$f_{R}$, breaths $\cdot \min ^{-1}$ & $28.1(5.7)$ & $30.4(6.3)^{*}$ & $28.3(5.1)$ & $28.4(4.3)$ & $0.049(2.865)$ \\
\hline$\dot{\mathrm{V}}_{\mathrm{E}}, \mathrm{L} \cdot \mathrm{min}^{-1}$ & $35.7(8.1)$ & $34.7(6.0)$ & $33.8(7.4)$ & $34.4(8.7)$ & $0.589(0.648)$ \\
\hline $\mathrm{V}_{\mathrm{D}} / \mathrm{V}_{\mathrm{T}}$ & $0.37(0.04)$ & $0.38(0.05)$ & $0.37(0.04)$ & $0.37(0.04)$ & $0.372(1.07 I)$ \\
\hline$\dot{\mathrm{V}}_{\mathrm{E}} / \dot{\mathrm{V}}_{\mathrm{O} 2}$ & $43.7(6.4)$ & $45.9(8.1)$ & $44.4(8.4)$ & $43.4(8.7)$ & $0.061(2.660)$ \\
\hline$\dot{\mathrm{V}}_{\mathrm{E}} / \dot{\mathrm{V}}_{\mathrm{CO} 2}$ & $44.9(5.8)$ & $46.7(6.8)$ & $45.0(7.0)$ & $45.4(8.0)$ & $0.189(1.669)$ \\
\hline $\mathrm{HR}$, beats $\cdot \mathrm{min}^{-1}$ & $12 \mid(12)$ & $123(14)$ & $124(11)$ & $123(\mathrm{II})$ & $0.592(0.749)$ \\
\hline SPO2, \% & $91.6(4.1)$ & $90.9(4.8)$ & $90.1(4.9)$ & $88.9(4.7)$ & $0.023(3.556)$ \\
\hline $\mathrm{DF}_{\mathrm{O} 2}, \%$ & $2.83(0.39)$ & $2.69(0.42)^{*}$ & $2.80(0.48)$ & $2.87(0.59)$ & $0.100(2.226)$ \\
\hline $\mathrm{PETCO}_{2}, \mathrm{mmHg}$ & $34.1(4.7)$ & $33.6(5.2)$ & $34.5(5.4)$ & 34.1 (6.2) & $0.288(1.298)$ \\
\hline $\mathrm{Fe}_{\mathrm{CO} 2}, \%$ & 3.01 (0.39) & $2.91(0.40)$ & $3.02(0.43)$ & $2.98(0.49)$ & 0.191 (1.661) \\
\hline
\end{tabular}

Notes: ATS/ERS Statement on respiratory muscle testing. Am J Respir Crit Care Med Data are presented as the mean (standard deviation). Treatment effect: mean difference from pre-treatment; ${ }^{*} \mathrm{P}<0.05$, ${ }^{* *} \mathrm{P}<0.0 \mathrm{I}$, ***P $<0.00 \mathrm{I}$ : pre-treatment vs I 2 weeks, paired $t$-test. ${ }^{\mathrm{a}}$ Time course effect of I 2 -week acupuncture treatment by oneway repeated measures analysis of variance.

Abbreviations: $\mathrm{DF}_{\mathrm{O} 2}$, difference between fractional content of inspired oxygen and fractional content of expired oxygen; Fe $\mathrm{CO}_{2}$, fractional content of expired carbon dioxide; $\mathrm{f}_{\mathrm{R}}$, breathing frequency; $\mathrm{HR}$, heart rate; $\mathrm{PETCO}_{2}$, end-tidal partial pressure of $\mathrm{CO}_{2}$; $\mathrm{SPO}_{2}$, saturation pulse oxygenation; $\mathrm{V}_{\mathrm{D}} / \mathrm{V}_{\mathrm{T}}$, dead space/tidal volume ratio; $\dot{\mathrm{V}}_{\mathrm{E}}$, minute ventilation; $\dot{\mathrm{V}}_{\mathrm{CO} 2}, \mathrm{CO}_{2}$ output; $\dot{\mathrm{V}}_{\mathrm{O} 2}$, oxygen uptake; $\mathrm{V}_{\mathrm{T}}$, tidal volume; $\mathrm{V}_{\mathrm{Ti}}-\mathrm{V}_{\mathrm{Te}}$, inspiratory tidal volume - expiratory tidal volume.

\section{Statistical Analysis}

The data are expressed as means \pm SD unless otherwise indicated and as means $\pm \mathrm{SE}$ in a part of Table and Figures. Changes in parameters at week 12 were assessed by the paired $t$-test. The time course (baseline, 12-week, 16-week, and 24-week) changes in parameters treated by 12 -week acupuncture were verified using one-way repeated-measures analysis of variance. The relationships between parameters were assessed using Pearson's correlation coefficients and linear regression analyses. A p-value $<0.05$ was considered statistically significant (JMP software, version 11; SAS Institute Inc., NC, United States).

\section{Results}

\section{Recruitment And Follow-Up}

Of the 20 patients meeting the defined criteria, 18 agreed to participate and underwent acupuncture (Figure 1). Of those, two female patients were unable to complete the study protocol because one patient was prescribed a steroid for rheumatoid arthritis, and the other patient was affected by depression. The follow-up assessments were not performed in two patients due to acute respiratory infections and severe arrhythmia in one patient. The baseline characteristics of the remaining 16 patients are shown in Table 1. Medications for all patients did not change throughout the study. All patients had previously undergone a CPET in the clinical practise.

\section{Primary Outcomes}

During the time course of 12 weeks of acupuncture, the $\dot{\mathrm{V}}_{\text {O2peak }}$ and $\dot{\mathrm{V}}_{\mathrm{E} \text { peak }}$ were significantly improved in IET (Table 2, Figure 2). The peak aerobic capacity improved by $>50 \mathrm{~mL} / \mathrm{min}$ from baseline in 5 of the $16(31 \%)$ patients. The $\mathrm{D}-\mathrm{Fo}_{2} \%$ significantly decreased at peak exercise after 12 weeks of acupuncture, although there were no effects on the $\mathrm{Spo}_{2}$-slope and $\mathrm{Spo}_{2}$.

The tLIM significantly increased after 12 weeks of acupuncture and in the follow-up in CWRET (Table 3, Figure 3). The tLIM improved by $>100 \mathrm{~s}$ after 12 weeks of acupuncture compared to baseline in 14 of the $16(88 \%)$ patients. After 12 weeks of acupuncture in CWRET, the $\dot{\mathrm{V}}_{\mathrm{O} 2}$ and the $\mathrm{D}-\mathrm{Fo}_{2} \%$ significantly decreased at terminated exercise, but minute ventilation did not change. The best improvement in tLIM, defined as the greatest percentage increase among three CWRETs in each patient, was 

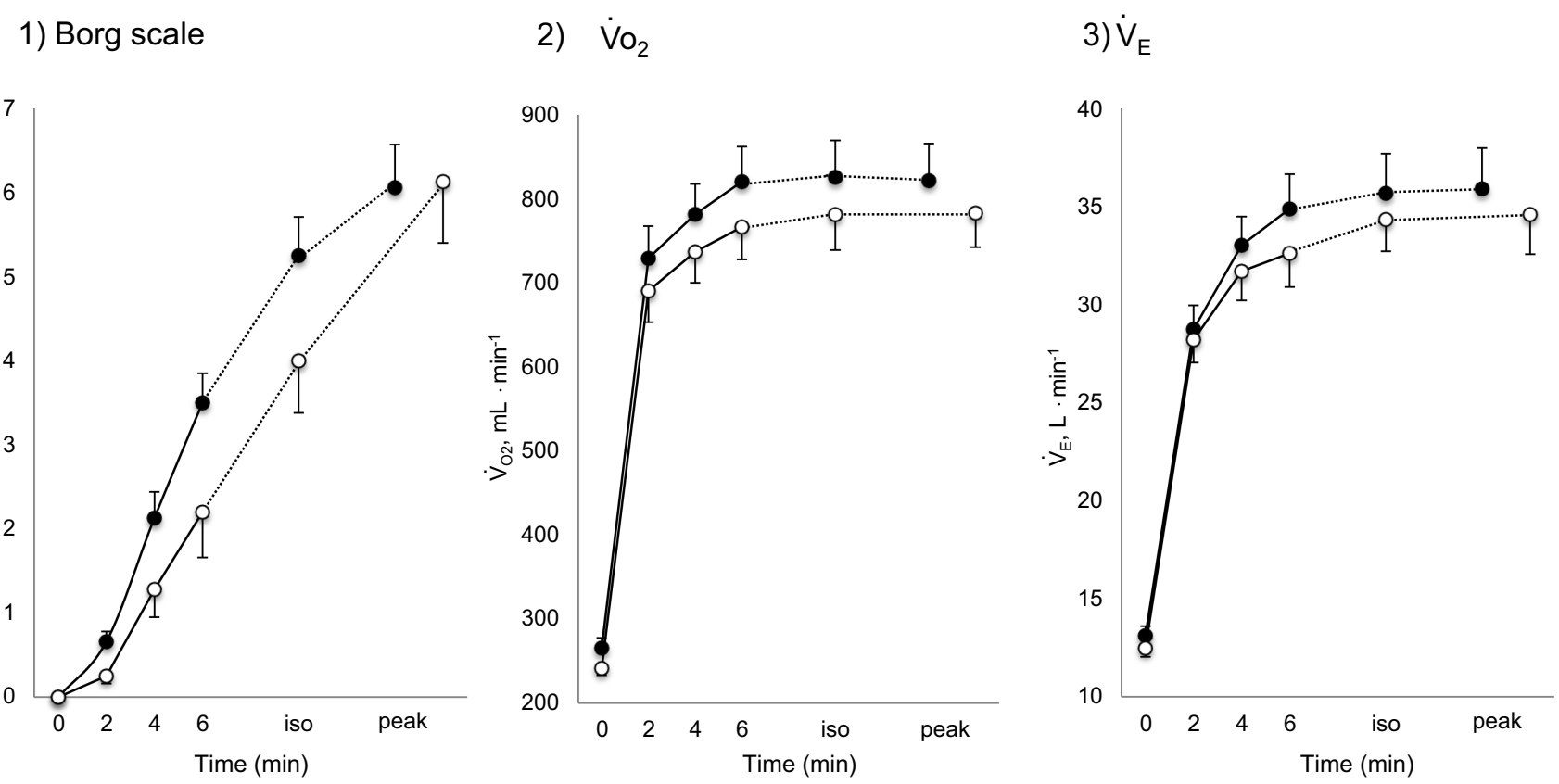

4)

\begin{tabular}{cccccc}
\hline \multicolumn{5}{c}{ The p-values between pre- and post-acupuncture values } & \\
Stage & $2 \mathrm{~min}$ & $4 \mathrm{~min}$ & $6 \mathrm{~min}$ & isotime & peak \\
\hline $\begin{array}{c}\text { Borg scale } \\
\dot{\mathrm{V}_{\mathrm{O} 2}}\end{array}$ & 0.0139 & 0.0315 & 0.0238 & 0.0034 & 0.8683 \\
$\dot{\mathrm{V}_{\mathrm{E}}}$ & 0.0188 & 0.0005 & 0.0032 & 0.0041 & 0.0605 \\
\hline
\end{tabular}

Figure 3 Increases in Borg scale scores, oxygen uptake $\left(\dot{\mathrm{V}}_{\mathrm{O} 2}\right)$, and minute ventilation $\left(\dot{\mathrm{V}}_{\mathrm{E}}\right)$ during constant work rate exercise testing $(\mathrm{CWRET})$ between baseline and (weeks 12 or 16) with the strongest improvement in time to the limit of tolerance (tLIM). Data are expressed as mean \pm standard error. Closed dots indicate baseline values, and open dots indicate the values of the week with the most improved tLIM. There was a significant improvement in the I) Borg scale scores and decrease in 2) $\dot{V}_{O 2}$ and 3 ) $\dot{V}_{E}$ throughout the CWRET. The p-values between pre- and post-acupuncture values in each stage were shown in 4) as Table.

observed at week 12 (8 patients) and 16 (remaining 8 patients). The SGRQ score, especially the symptom score, was significantly improved at 12 and 24 weeks (Table 4).

\section{Secondary Outcomes}

After completing 12 weeks of acupuncture, there were improvements in respiratory muscle strength (i.e., MIP and MEP), but there were no changes in $\mathrm{FEV}_{1}$, total lean body mass, and total energy expenditure (Table 4 ).

\section{Parameters Contributing To Best tLIM Improvement After Acupuncture}

After acupuncture, dyspnoea significantly improved at 2 , 4, 6 mins and isotime, the $\dot{\mathrm{V}}_{\mathrm{O} 2}$ was significantly decreased at 2, 4, 6 mins and isotime, and $\dot{\mathrm{V}}_{\mathrm{E}}$ significantly decreased at 4, 6 mins and isotime during CWRET (Figure 3). In the stages showing significant changes from the pre-acupuncture, 1) the decreases in the Borg scale at 6 mins $(r=-0.608, p=0.0211)$ and isotime $(r=-0.789$, $\mathrm{p}=0.0007)$, and $\dot{\mathrm{V}}_{\mathrm{E}}$ at 6 mins $(\mathrm{r}=-0.5809, \mathrm{p}=0.0294)$ and isotime $(\mathrm{r}=-0.6736, \mathrm{p}=0.0042)$ were significantly correlated with the improvement (sec) of tLIM improvement (Figure 4). 2) The decrease in $\dot{\mathrm{V}}_{\mathrm{O} 2}$ at isotime was not significantly correlated to tLIM improvements $(\mathrm{r}=-0.4587, \mathrm{p}=0.0739)$. 3) The increases in $\mathrm{D}-\mathrm{F}_{\mathrm{O} 2} \%$ at isotime $(r=0.6884, p=0.0032)$ were positively correlated with the improvement (sec) of tLIM (Table 5; Figure 4). 4) The decreases in the modified Borg scale $(\mathrm{r}=-0.6795, \mathrm{p}=0.0038)$ and $\dot{\mathrm{V}}_{\mathrm{E}}(\mathrm{r}=-0.6880$, $\mathrm{p}=0.0032)$ were significantly correlated with the $\mathrm{D}-\mathrm{F}_{\mathrm{O} 2} \%$ changes at isotime.

The $\left(\mathrm{V}_{\mathrm{Ti}}-\mathrm{V}_{\mathrm{Te}}\right)$ was significantly decreased at isotime $(16.7 \pm 4.1$ to $3.3 \pm 4.2, \mathrm{p}=0.0327)$ after acupuncture, and 
Table 4 St George's Respiratory Questionnaire Scores, Pulmonary Functions, And Other Parameters After 12 Weeks Of Acupuncture Treatment And Follow-Up Data

\begin{tabular}{|c|c|c|c|c|}
\hline & Week $0(n=16)$ & Week I $2(n=16)$ & Week $24(n=14)$ & p-Value (F-Value) ${ }^{a}$ \\
\hline \multicolumn{5}{|l|}{ SGRQ scores } \\
\hline Total & $40.4(16.3)$ & $35.0(15.4)^{*}$ & $35.2(16.0)$ & $0.009(5.577)$ \\
\hline Symptoms & $49.9(22.7)$ & $40.7(17.7)^{*}$ & $42.3(17.4)$ & $0.029(4.019)$ \\
\hline Activity & $56.9(17.9)$ & $52.2(18.8)$ & $51.7(21.6)$ & $0.020(4.542)$ \\
\hline Impacts & $28.1(17.0)$ & $23.4(15.2)$ & $24.3(17.5)$ & $0.110(2.392)$ \\
\hline \multicolumn{5}{|l|}{ Pulmonary function tests } \\
\hline $\mathrm{FEV}_{\mathrm{l}}, \mathrm{L}$ & $\mathrm{I} .42(0.54)$ & $\mathrm{I} .39(0.5 \mathrm{I})$ & $1.46(0.55)$ & $0.358(1.067)$ \\
\hline$\% \mathrm{FEV}_{1}, \%$ & $51.6(18.9)$ & $50.8(18.6)$ & $52.4(20.2)$ & $0.532(0.646)$ \\
\hline $\mathrm{FEV}_{\mathrm{I}} / \mathrm{FVC}, \%$ & $43.0(13.8)$ & $43.6(16.1)$ & $44.4(14.2)$ & $0.915(0.089)$ \\
\hline $\mathrm{VC}, \mathrm{L}$ & $3.32(0.52)$ & $3.28(0.55)$ & $3.42(0.49)$ & $0.273(1.359)$ \\
\hline$\%$ VC, \% & $93.7(12.2)$ & $92.5(12.9)$ & $95.5(13.8)$ & $0.247(1.473)$ \\
\hline \multicolumn{5}{|l|}{ Others } \\
\hline MIP, $\mathrm{cmH}_{2} \mathrm{O}$ & $-50.7(I 7.4)$ & $-58.3(17.2)^{*}$ & $-53.8(16.9)$ & $0.029(4.006)$ \\
\hline MEP, $\mathrm{cmH}_{2} \mathrm{O}$ & $53.4(16.9)$ & $60.6(18.8)^{* *}$ & $56.0(21.2)$ & $0.111(2.378)$ \\
\hline Total lean body mass, $\mathrm{kg}$ & $43.4(4.5)$ & $43.7(4.2)$ & $43.1(3.6)$ & $0.992(0.303)$ \\
\hline Total energy expenditure, $\mathrm{kcal} \cdot$ day $^{-1}$ & $1812(189)$ & $1789(2 \mid 8)$ & $|85|(\mid 84)$ & $0.201(1.705)$ \\
\hline $\mathrm{R} 5, \mathrm{cmH}_{2} \mathrm{O} \cdot \mathrm{L}^{-1} \cdot \mathrm{s}^{-1}$ & $3.9(1.7)$ & $3.9(1.2)$ & $3.9(1.6)$ & $0.999(0.001)$ \\
\hline $\mathrm{R} 20, \mathrm{cmH}_{2} \mathrm{O} \cdot \mathrm{L}^{-1} \cdot \mathrm{s}^{-1}$ & $2.9(1.1)$ & $2.9(0.8)$ & $2.9(1.1)$ & $0.999(0.001)$ \\
\hline
\end{tabular}

Notes: Data are presented as the mean (standard deviation). ${ }^{*} \mathrm{P}<0.05$, $* * \mathrm{P}<0.01$ : pre-treatment vs 12 weeks, paired $t$-test. ${ }^{\text {a }}$ Time course effect of 12 -week acupuncture treatment by one-way repeated measures analysis of variance.

Abbreviations: $\mathrm{FEV}_{1}$, forced expiratory volume in one second; FVC, forced vital capacity; MEP, maximal expiratory pressure; MIP, maximal inspiratory pressure; R5, respiratory system resistance at $5 \mathrm{~Hz}$; R20, respiratory system resistance at $20 \mathrm{~Hz}$; SGRQ, St George's Respiratory Questionnaire; VC, vital capacity.

this decrease was correlated with the decrease in $\dot{\mathrm{V}}_{\mathrm{E}}(\mathrm{r}=0.606$, $\mathrm{p}=0.0129$ ). In addition, the improvement (sec) of tLIM was significantly correlated with the respiratory gas exchange ratio $(\mathrm{r}=-0.5587, \mathrm{p}=0.0244)$ at isotime in CWRET, but not with the improvement of $\dot{\mathrm{V}}_{\text {O2peak }}$ and peak $\dot{\mathrm{V}}_{\mathrm{E}}$ in IET after acupuncture. Consequently, improvements in dyspnoea, reduction in $\dot{\mathrm{V}}_{\mathrm{E}}$, and the increase of $\mathrm{D}-\mathrm{F}_{\mathrm{O} 2} \%$ between post- and preacupuncture values at isotime have greatly contributed to the improvement (sec) of tLIM (Figure 4).

\section{Adverse Reactions}

Some patients reported 1 fatigue, 3 subcutaneous bleedings, and 2 pains at the needle insertion site as adverse reactions. All events were minor responses and patients recovered within a short time. Significant events caused by the acupuncture procedure have not been reported.

\section{Discussion}

The effects of acupuncture, applied once a week for 12 weeks in stable COPD patients, were evaluated at baseline and at 12 , 16 , and 24 weeks, and the underlying pathophysiological mechanisms were analysed using CPET. We observed improvements in $\dot{\mathrm{V}}_{\text {O2peak }}, \dot{\mathrm{V}}_{\mathrm{E} \text { peak }}$, tLIM, and dyspnoea including SGRQ score after acupuncture. Thus, this study confirmed the effectiveness of acupuncture using CPET in the previous study. ${ }^{13}$ The improvement of exercise intolerance largely contributed to the increase in tLIM rather than in $\dot{\mathrm{V}}_{\text {O2peak }}$ based on the minimal clinically important differences, which were considered as a $\dot{\mathrm{V}}_{\text {O2peak }}$ change of $50 \mathrm{~mL} / \mathrm{min}$ and tLIM change of $100 \mathrm{s.}^{23}$ Following acupuncture, the $\dot{\mathrm{V}}_{\mathrm{O} 2}$ values, calculated using the product of $\dot{\mathrm{V}}_{\mathrm{E}} \times \mathrm{D}-\mathrm{F}_{\mathrm{O} 2} \%$, were low throughout the CWRET. From the pre-acupuncture, the decrease in $\dot{\mathrm{V}}_{\mathrm{E}}$ and Borg scale and increase in $\mathrm{D}-\mathrm{F}_{\mathrm{O} 2} \%$ at isotime significantly contributed to tLIM improvement.

In the two cases without tLIM improvement of $100 \mathrm{~s}$ (cases 17 and 18 in Table 5), the $\mathrm{Sp}_{\mathrm{O} 2}$-slope, indicative of pulmonary gas exchange, was clearly deteriorated. Furthermore, case 17 had a very severe obstructive disorder ( $\mathrm{FEV}_{1} \%$ predicted: $\left.26.6 \%\right)$ and lost $3.1 \mathrm{~kg}$ of bodyweight during the study period. The respiratory muscle strength was also decreased (MEP, 56.9 to $45.8 \mathrm{cmH}_{2} \mathrm{O}$; MIP, 51.5 to $39.5 \mathrm{cmH}_{2} \mathrm{O}$ ); moreover, the parameter $\mathrm{V}_{\mathrm{Ti}^{-}}$ $\mathrm{V}_{\mathrm{Te}}$, representing the remaining volume of expiration was increased to $+32 \mathrm{~mL}$. In case 18 , the C-reactive protein 
Table 5 Improvement In Time To The Limit Of Tolerance In Constant Workload Exercise Testing And Related Parameters In Each Patient

\begin{tabular}{|c|c|c|c|c|c|c|c|c|c|c|c|}
\hline \multirow[b]{3}{*}{ Case No. } & \multicolumn{8}{|c|}{ Constant Workload Exercise Testing } & \multicolumn{3}{|c|}{ Incremental Exercise Testing } \\
\hline & \multicolumn{2}{|c|}{$\begin{array}{c}\text { tLIM } \\
\text { Improvement }\end{array}$} & \multicolumn{6}{|c|}{ Parameters At Isotime } & \multicolumn{2}{|c|}{ Improvement (\%) } & \multirow[b]{2}{*}{$\Delta$ Spo2-Slope } \\
\hline & s & $\%$ & $\mathbf{R}$ ratio & $\Delta \mathrm{BS}$ & $\Delta \dot{\mathrm{V}}_{\mathbf{O 2}}$ & $\Delta \dot{\mathrm{V}}_{\mathbf{E}}$ & $\Delta \mathrm{D}-\mathbf{F}_{\mathrm{O} 2}$ & $\Delta \mathrm{V}_{\mathbf{T i}}-\mathrm{V}_{\mathbf{T e}}$ & $\dot{V}_{\text {O2peak }}$ & peak $\dot{\mathrm{V}}_{\mathrm{E}}$ & \\
\hline I & 1510 & 385 & 0.92 & -4 & -80 & -6.5 & 0.49 & -14 & -2.2 & 2.3 & -2 \\
\hline 2 & 1089 & 58 & 0.98 & -3 & -112 & -7.1 & 0.24 & -77 & 16.0 & 13.3 & 0.5 \\
\hline 4 & 656 & 120 & 0.98 & -2 & -33 & 0 & -0.10 & 11 & 17.5 & 26.7 & 4.6 \\
\hline 5 & 602 & 45 & 0.94 & -2 & -4 & -3.6 & 0.20 & -21 & -12.9 & 1.7 & -4 \\
\hline 6 & 558 & 85 & 1.00 & -2 & -61 & 0 & -0.20 & 17 & 4.9 & 4.7 & -2.4 \\
\hline 7 & 554 & 52 & 0.94 & -2 & 32 & 1.2 & 0.27 & -7 & 23.1 & 27.7 & 29.9 \\
\hline 8 & 447 & 52 & 0.97 & -1 & 8 & -3.4 & 0.15 & -48 & 3.2 & -4.7 & 0.2 \\
\hline 10 & 334 & 19 & 0.97 & 0 & -96 & 2.2 & -0.50 & 21 & -5.2 & 9.1 & -1.2 \\
\hline 11 & 333 & 95 & 0.89 & -2 & 32 & 0.8 & 0.03 & -2 & 4.0 & 9.0 & -0.8 \\
\hline 12 & 266 & 51 & 1.00 & -2 & -33 & 0 & -0.10 & -8 & 4.5 & 5.2 & -2.9 \\
\hline 13 & 263 & 34 & 0.99 & 1 & -65 & -3.0 & 0.01 & -31 & 6.3 & 1.0 & 2.5 \\
\hline 14 & 212 & 39 & 1.02 & -1 & -36 & -0.2 & -0.10 & -15 & 6.3 & 4.5 & 0.2 \\
\hline 15 & 123 & 20 & 1.08 & 1 & -162 & 0.4 & -0.30 & -19 & 4.7 & 7.1 & -3.9 \\
\hline 16 & 118 & 16 & 1.05 & -1 & -21 & -1.7 & 0.03 & -35 & 16.1 & 24.7 & -8.5 \\
\hline 17 & 20 & 4 & 0.99 & 1 & -64 & -2.2 & -0.20 & 32 & -5.7 & -3.8 & -13.2 \\
\hline 18 & 16 & 5 & 1.14 & -1 & -15 & 2.1 & -0.10 & -12 & 7.1 & 5.5 & -14.4 \\
\hline Mean \pm SE & $444 \pm 99$ & $68 \pm 23$ & $0.99 \pm 0.02$ & $-1.3 \pm 0.4$ & $-44 \pm 13$ & $-1.3 \pm 0.7$ & $-0.01 \pm 0.06$ & $-13.4 \pm 6.8$ & $5.5 \pm 2.4$ & $8.4 \pm 2.5$ & $-0.9 \pm 2.4$ \\
\hline
\end{tabular}

Notes: Differences $(\Delta)$ between post- and pre-acupuncture measurement are shown for the following: BS, Borg scale; D-F

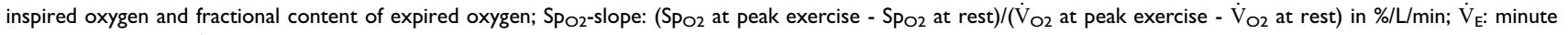
ventilation in $\mathrm{L} / \mathrm{min}$; $\dot{\mathrm{V}}_{\mathrm{O} 2}$, oxygen uptake in $\mathrm{mL} / \mathrm{min} ; \mathrm{V}_{\mathrm{Ti}_{\mathrm{i}}}-\mathrm{V}_{\mathrm{Te}}$ : inspiratory tidal volume - expiratory tidal volume in $\mathrm{mL}$.

Abbreviations: $\mathrm{R}$ ratio, gas exchange ratio $\left(\dot{\mathrm{V}}_{\mathrm{CO}_{2}} / \dot{\mathrm{V}}_{\mathrm{O}}\right)$; $\mathrm{SE}$, standard error; tLIM, time to the limit of tolerance.

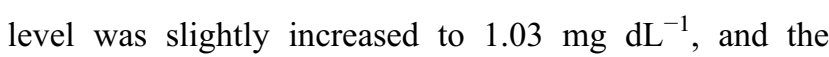
respiratory system resistance values were also increased at week $12\left(\mathrm{R} 5,2.7\right.$ to $5.4 \mathrm{cmH}_{2} \mathrm{O} \mathrm{L}^{-1} \mathrm{~s}^{-1}$; R20, 2.4 to $3.9 \mathrm{cmH}_{2} \mathrm{O} \mathrm{L}^{-1} \mathrm{~s}^{-1}$ ). And then, this patient withdrew from the study due to pneumonia. Given these results, it is understandable that their endurance times were not improved by acupuncture.

The effects of acupuncture on $\dot{\mathrm{V}}_{\text {O2peak }}$, tLIM, and quality of life continued to be observable at 24 weeks. By contrast, the effects on respiratory muscle strength, $\dot{\mathrm{V}}_{\mathrm{O} 2}$ and D-FO (\%) at terminated exercise in CWRET tended to decline. It is generally unlikely that acupuncture effects will sustain over 12 weeks after terminating the treatment. Of the 16 participants, 11 had previously undergone the PPR-OT program at our institute, ${ }^{10}$ and the remaining 5 participants had been riding bicycles in everyday life. The PPR-OT program included practical guidance regarding inhalation therapy, exercise training in a home setting, nutrition and diet therapy, and self-management. We speculated that these daily exercises sustained the effects of acupuncture. Further studies are necessary to determine the synergistic effect between exercise training and acupuncture.
The improvements in pulmonary functions and nutritional status observed in previous papers were not replicated in our study, ${ }^{13,25}$ although the same acupuncture points were used. However, we used a thinner needle $(0.16 \mathrm{~mm}$ vs $0.35 \mathrm{~mm})$ in this study because of the weak pain stimulus. An improvement of $\mathrm{FEV}_{1}$ has also been observed in patients with COPD who are treated with transcutaneous electrical nerve stimulation, which was associated with a concurrent increase in $\beta$-endorphin levels. ${ }^{26}$ The increase in $\beta$-endorphin levels also correlated with a reduction in breathing frequency. ${ }^{27} \mathrm{~A}$ significant decrease in breathing frequency was not observed in the current study, which may be due to a weaker pain stimulus and/or differences in acupuncture procedures. Although the detailed reasons for the observed differences in our study findings compared to previous findings are unknown, our data might have been influenced by baseline managements, including appropriate medications (i.e., inhalation therapy) and pulmonary rehabilitation.

Patients with COPD experience tension and fatigue of both main and accessory respiratory muscles; therefore, many of the acupuncture points used in the present study 


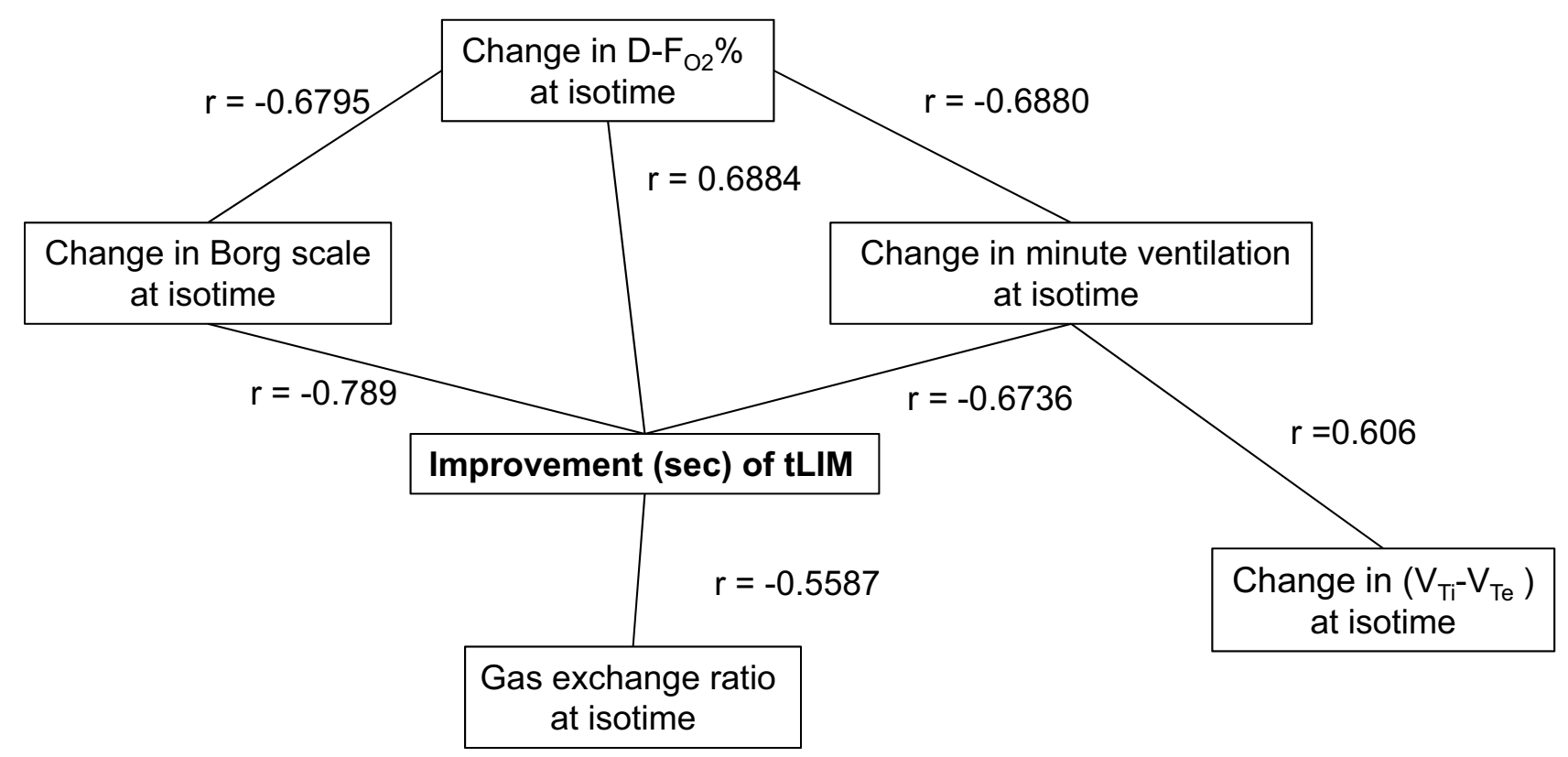

Figure 4 Relationships between Improvement in time to the limit of tolerance and parameters at isotime in constant work rate exercise testing (CWRET).

Abbreviations: tLIM, time to the limit of tolerance, $\mathrm{DF}_{\mathrm{O} 2}(\%)$, inspired oxygen concentration $\left(\mathrm{Fi}_{\mathrm{O} 2}\right)$ - expired oxygen concentration (Fe 2 ); $\mathrm{V}_{\mathrm{Ti}_{\mathrm{i}}}-\mathrm{V}_{\mathrm{Te}}$, inspiratory tidal volume - expiratory tidal volume.

corresponded to those accessory muscles. ${ }^{13}$ We believe that acupuncture decreases the tone of accessory muscles and alleviates muscle fatigue, leading to a significant improvement in respiratory muscle strength (MEP/MIP) and peak $\dot{\mathrm{V}}_{\mathrm{E}}{ }^{14}$ Respiratory muscle unloading may also improve the oxygen supply to lower-limb muscles. ${ }^{28}$ This effect may be due to the ability of acupuncture to reduce myostatin gene expression, leading to muscle satellite cell proliferation and activation of muscle protein synthesis. Consequently, muscle atrophy is reduced and muscle strength is restored. ${ }^{29,30}$ Improvements in muscle blood flow were indicated by an increase in muscle oxygenation and blood volume, which may be caused by calcitonin gene and peptide-related antidromic local vasodilation and the axon reflex in the muscle stimulated by acupuncture. $^{15,31,32}$ Furthermore, electrical acupuncture stimulation showed increased blood fluidity in an animal study. This effect might involve an endogenous adrenergic mechanism because it was inhibited by a $\beta$-antagonist. ${ }^{33}$ We hypothesised that improvements in muscle strength and circulation after acupuncture may have contributed to the lower $\dot{\mathrm{V}}_{\mathrm{O} 2}$ and $\dot{\mathrm{V}}_{\mathrm{E}}$ values throughout the CWRET. No effects on pulmonary gas exchange were observed; therefore, the responses of $\mathrm{D}-\mathrm{F}_{\mathrm{O} 2} \%$ at isotime may be caused by an improved oxygen utilisation in the muscle. Although the IET did not detect a significant AT increase, the acupuncture-induced tLIM increase likely reflects a delayed onset of metabolic and/or respiratory acidosis due to the lowered oxygen consumption per workload because decreases in respiratory gas exchange ratio at isotime after acupuncture were significantly correlated with tLIM improvements. ${ }^{21}$ Furthermore, this effect on oxygen utilisation may improve the prognosis of COPD as well as outcomes of occupational therapy. ${ }^{10}$

The limitations of this study were as follows: 1) blood samples (to determine arterial blood gases, lactate, catecholamine, or $\beta$-endorphin) were not collected for the elucidation of pathophysiological mechanism because of financial constraints; 2) for the more accurate measurement of exercise tolerance, the tLIM at baseline in the CWRET (at 70\% peak WR of the IET) was longer than the recommended value and the optimal time point for acupuncture-induced improvements should be determined in advance. $^{23}$

\section{Conclusion}

The effectiveness of acupuncture was due to the improvements in ventilation capacity in IETs and the increase of endurance time in CWRETs at 12 weeks. In the CWRET, the values of oxygen uptake during exercise and at terminated exercise were significantly lower after acupuncture than those at baseline. These results indicate that COPD patients treated with acupuncture have been able to exercise with less oxygen consumption. Our findings indicate 
that acupuncture may be a new intervention for COPD in addition to conventional maintenance therapies.

\section{Ethics Approval And Informed Consent And Consent For Publication}

This study was performed in accordance with the Declaration of Helsinki and its amendments, the Guidelines for Good Clinical Practice for Epidemiological Studies, the Standards for Reporting Interventions in Clinical Trials of Acupuncture (STRICTA), and the Guidelines for Clinical Research issued by the Japanese Ministry of Health. The institutional review board of the National Hospital Organization Osaka Toneyama Medical Center approved this study (number: 1580), and each patient provided written informed consent. The study protocol is registered at the University Hospital Medical Information Network in Japan (UMIN000017609).

\section{Data Availability}

The authors confirm that the data supporting the findings of this study are available within the article.

\section{Acknowledgments}

We thank Professor Kenji Namura (Meiji University of Integrative Medicine) and Mr. Teranishi T. (CMIC Holdings Co., Ltd. Tokyo, Japan) for their assistance in statistical analysis. This study received Grant-in-Aid for Clinical Research from National Hospital Organization in Japan.

\section{Author Contributions}

All authors contributed to data analysis, drafting and revising the article, gave final approval of the version to be published, and agree to be accountable for all aspects of the work.

\section{Disclosure}

The authors report no conflicts of interest in this work.

\section{References}

1. WHO. The top 10 causes of death. Available from: https://www.who. int/news-room/fact-sheets/detail/the-top-10-causes-of-death. [updated May 24, 2018]. Accessed April 18, 2019.

2. Laviolette L, Laveneziana P. ERS Research Seminar Faculty. Dyspnoea: a multidimensional and multidisciplinary approach. Eur Respir J. 2014;43:1750-1762. doi:10.1183/09031936.00092613

3. Parshall MB, Schwartzstein RM, Adams L, et al; American Thoracic Society Committee on Dyspnea. An official American Thoracic Society statement: update on the mechanisms, assessment, and management of dyspnea. Am J Respir Crit Care Med. 2012;185:435-452. doi:10.1164/rccm.201111-2042ST
4. Grønseth R, Vollmer WM, Hardie JA, et al. Predictors of dyspnoea prevalence: results from the BOLD study. Eur Respir J. 2014;43:1610-1620. doi:10.1183/09031936.00036813

5. Nishimura K, Izumi T, Tsukino M, Oga T. Dyspnea is a better predictor of 5-year survival than airway obstruction in patients with COPD. Chest. 2002;121:1434-1440. doi:10.1378/chest.121.5.1434

6. O'Donnell DE, Flüge T, Gerken F, et al. Effects of tiotropium on lung hyperinflation, dyspnoea and exercise tolerance in COPD. Eur Respir J. 2004;23:832-840. doi:10.1183/09031936.04.00116004

7. O'Donnell DE, Sciurba F, Celli B, et al. Effect of fluticasone propionate/salmeterol on lung hyperinflation and exercise endurance in COPD. Chest. 2006;130:647-656. doi:10.1378/chest.130.3.647

8. Spruit MA, Singh SJ, Garvey C, et al; ATS/ERS Task Force on Pulmonary Rehabilitation. An official American Thoracic Society/ European Respiratory Society statement: key concepts and advances in pulmonary rehabilitation. Am J Respir Crit Care Med. 2013;188: e13-e64. doi:10.1164/rccm.201309-1634ST

9. Marciniuk DD, Goodridge D, Hernandez P, Canadian Thoracic Society COPD Committee Dyspnea Expert Working Group, et al. Managing dyspnea in patients with advanced chronic obstructive pulmonary disease: a Canadian Thoracic Society clinical practice guideline. Can Respir J. 18;2011:69-78. doi:10.1155/2011/74 5047

10. Maekura R, Hiraga T, Miki K, et al. Personalized pulmonary rehabilitation and occupational therapy based on cardiopulmonary exercise testing for patients with advanced chronic obstructive pulmonary disease. Int J Chron Obstruct Pulmon Dis. 2015;10:1787-1800. doi:10.2147/COPD

11. Spruit MA, Augustin IM, Vanfleteren LE, et al; CIRO+ Rehabilitation Network. Differential response to pulmonary rehabilitation in COPD: multidimensional profiling. Eur Respir $J$. 2015;46:1625-1635. doi:10.1183/13993003.00350-2015

12. Jobst K, Chen JH, McPherson K, et al. Controlled trial of acupuncture for disabling breathlessness. Lancet. 1986;2:1416-1419. doi:10.1016/S0140-6736(86)92732-7

13. Suzuki M, Muro S, Ando Y, et al. A randomized, placebo-controlled trial of acupuncture in patients with chronic obstructive pulmonary disease (COPD): the COPD-acupuncture trial (CAT). Arch Intern Med. 2012;172:878-886. doi:10.1001/archinternmed.2012.1233

14. Kawakita K, Itoh K, Okada K. Experimental model of trigger points using eccentric exercise. J Musculoskelet Pain. 2008;16:29-35. doi:10.1080/10582450801960180

15. Shinbara H, Okubo M, Sumiya E, Fukuda F, Yano T, Kitade T. Effects of manual acupuncture with sparrow pecking on muscle blood flow of normal and denervated hindlimb in rats. Acupunct Med. 2008;26:149-159. doi:10.1136/aim.26.3.149

16. Cagnie B, Barbe T, De Ridder E, Van Oosterwijck J, Cools A, Danneels L. The influence of dry needling of the trapezius muscle on muscle blood flow and oxygenation. J Manipulative Physiol Ther. 2012;35:685-691. doi:10.1016/j.jmpt.2012.10.005

17. Global Initiative for Chronic Obstructive Lung Disease. GOLD. Global strategy for the diagnosis, management and prevention of COPD. 2011. Available from: https://goldcopd.org. [updated May 24, 2018]. Accessed April 18, 2019

18. Statement of the American Thoracic Society. Am Rev Respir Dis. 1987;136:1285-1298. doi:10.1164/ajrccm/136.5.1285

19. Standardization of spirometry, 1994 update. American Thoracic Society. Am J Respir Crit Care Med. 1995;152:1107-1136. doi:10.1164/ajrccm.152.3.7663792

20. Miki K, Maekura R, Hiraga T, et al. Acidosis and raised norepinephrine levels are associated with exercise dyspnoea in idiopathic pulmonary fibrosis. Respirology. 2009;14:1020-1026. doi:10.1111/ res.2009.14.issue-7

21. Maekura R, Hiraga T, Miki K, et al. Differences in physiological response to exercise in patients with different COPD severity. Respir Care. 2014;59:252-262. doi:10.4187/respcare.02201 
22. Borg GA. Psychophysical basis of perceived exertion. Med Sci Sports Exerc. 1982;14:377-381. doi:10.1249/00005768-198205000-00012

23. Puente-Maestu L, Palange P, Casaburi R, et al. Use of exercise testing in the evaluation of interventional efficacy: an official ERS statement. Eur Respir J. 2016;47:429-460. doi:10.1183/13993003.00745-2015

24. American Thoracic Society/European Respiratory Society. ATS/ERS statement on respiratory muscle testing. Am J Respir Crit Care Med. 2002;166:518-624.

25. Suzuki M, Muro S, Fukui M, et al. Effects of acupuncture on nutritional state of patients with stable chronic obstructive pulmonary disease (COPD): re-analysis of COPD acupuncture trial, a randomized controlled trial. BMC Complement Altern Med. 2018;18:287. doi:10.1186/s12906-018-2341-3

26. Ngai SP, Jones AY, Hui-Chan CW, Ko FW, Hui DS. Effect of 4 weeks of Acu-TENS on functional capacity and beta-endorphin level in subjects with chronic obstructive pulmonary disease: a randomized controlled trial. Respir Physiol Neurobiol. 2010;173:29-36. doi:10.1016/j.resp.2010.06.005

27. Jones AY, Ngai SP, Hui-Chan CW, Yu HP. Acute effects of AcuTENS on FEV1 and blood B-endorphin level in chronic obstructive pulmonary disease. Altern Ther Health Med. 2011;17:8-13.

28. Berton DC, Barbosa PB, Takara LS, et al. Bronchodilators accelerate the dynamics of muscle $\mathrm{O} 2$ delivery and utilisation during exercise in COPD. Thorax. 2010;65:588-593. doi:10.1136/thx.2009.120857
29. Takaoka Y, Ohta M, Ito A, et al. Electroacupuncture suppresses myostatin gene expression: cell proliferative reaction in mouse skeletal muscle. Physiol Genomics. 2007;30:102-110. doi:10.1152/ physiolgenomics.00057.2006

30. Gilson H, Schakman O, Kalista S, Lause P, Tsuchida K, Thissen JP. Follistatin induces muscle hypertrophy through satellite cell proliferation and inhibition of both myostatin and activin. Am J Physiol Endocrinol Metab. 2009;297:E157-E164. doi:10.1152/ajpend o.00193.2009

31. Hisashi S, Masamichi O, Keisaku K, Kunio M, Eiji S, Toshikatsu $\mathrm{K}$. Effects of manual acupuncture with the Japanese traditional needle manipulation on skeletal muscle blood flow and arterial blood pressure in rats-a comparison of the techniques. JAM. 2011; 7:15-21.

32. Ohkubo M, Hamaoka T, Niwayama $M$, et al. Local increase in trapezius muscle oxygenation during and after acupuncture. Dyn Med. 2009;8:2. doi:10.1186/1476-5918-8-2

33. Ishikawa S, Suga H, Fukushima M, et al. Blood fluidity enhancement by electrical acupuncture stimulation is related to an adrenergic mechanism. J Acupunct Meridian Stud. 2012;5:21-28. doi:10.1016/ j.jams.2011.11.003

\section{Publish your work in this journal}

The International Journal of COPD is an international, peer-reviewed journal of therapeutics and pharmacology focusing on concise rapid reporting of clinical studies and reviews in COPD. Special focus is given to the pathophysiological processes underlying the disease, intervention programs, patient focused education, and self management protocols. This journal is indexed on PubMed Central, MedLine and CAS. The manuscript management system is completely online and includes a very quick and fair peer-review system, which is all easy to use. Visit http://www.dovepress.com/testimonials.php to read real quotes from published authors. 